\title{
ANALISIS PENGARUH BEBAN KERJA DAN KOMITMEN ORGANISASI TERHADAP KINERJA KARYAWAN MELALUI TURNOVER INTENTION SEBAGAI VARIABEL INTERVENING
}

\author{
Ryan Aulia Authar \\ Universitas Muria Kudus
}

Email korespondensi: 201511019@std.umk.ac.id

\begin{abstract}
Company always expects its employees to have achievements, because having employees who excel will provide optimal contributions to the company. Good human resources management will lead to achieving goals. Therefore, it is important to analyze of the influence of workload and organizational commitment on employee performance through turnover intention. The purpose of this study was to analyze the effect of workload and organizational commitment on employee performance through turnover intention, the effect of workload and organizational commitment on turnover intention directly or indirectly as an intervening variable. The sample of this study were 140 people. The sampling technique used the proportional random sampling method. Data analysis method uses Structural Equation Modeling (SEM). The results of the study are that workload has a significant positive effect on turnover intention. Organizational commitment has a negative and significant effect on turnover intention. Workload has a significant positive effect on employee performance. Organizational commitment has a significant positive effect on employee performance. Turnover intention has a negative and significant effect on employee performance. Workload does not have a significant effect on employee performance through turnover intention. Organizational commitment has a significant effect on employee performance through turnover intention.
\end{abstract}

Keywords: Workload, Organizational Commitment, Employee Performance, Turnover Intention

\section{A. PENDAHULUAN}

Perusahaan selalu mengharapkan karyawannya mempunyai prestasi, karena dengan memiliki karyawan yang berprestasi akan memberikan sumbangan yang optimal bagi perusahaan. Jika individu dalam perusahaan yaitu sumber daya manusia berjalan efektif, maka perusahaan juga tetap berjalan efektif. Karyawan sebagai sumber daya manusia merupakan kunci keberhasilan organisasi. Pengelolaan sumber daya manusia yang baik akan mendorong ke arah pencapaian tujuan (Irvianti dan Verina, 2015). Sumber daya manusia merupakan aset perusahaan paling berharga dan paling rumit penanganannya, pengambilan kebijakan yang tidak tepat terkait permasalahan sumber daya manusia akan berdampak pada penurunan kinerja karyawan sehingga tujuan perusahaan akan sulit tercapai.

Keberhasilan suatu perusahaan dalam mencapai tujuannya tidak hanya bergantung pada sarana dan prasaran yang ada, tetapi juga bergantung pada kinerja karyawannya. Kinerja suatu 
perusahaan juga ditentukan oleh kondisi dan perilaku karyawan yang dimiliki perusahaan tersebut (Zaki dan Marzolina, 2016). Kinerja karyawan merupakan perhatian utama bagi semua organisasi bisnis. Banyak organisasi memiliki kebijakan di tingkat manajerial yang tidak memadai, sehingga hal ini dapat mempengaruhi kinerja karyawan (Syed ,et al; 2014).

Permasalahan yang dialami oleh perusahaan dalam hal ini adalah beban kerja yang terbilang cukup banyak yang diberikan kepada karyawannya. Misalkan, bagian gudang harus menyelesaikan pekerjaannya seperti bongkar muat barang hingga tengah malam dengan uang lembur yang tidak seberapa. Bagian pengiriman pun juga mendapat beban kerja yang cukup banyak. Terkadang ketika ada pesanan barang dari konsumen yang ingin hari itu juga dikirim padahal saat itu sudah waktunya pulang ke rumah mau tidak mau bagian pengiriman harus mengirim barangnya hingga larut malam. Inilah yang bisa menjadi pemicu menurunnya loyalitas dan kesiapan menjalankan tugas dari perusahaan. Hal ini mengakibatkan para karyawan berkeinginan untuk meninggalkan pekerjaan agar mendapatkan pekerjaan yang tidak menguras emosi dan tenaga karyawan. Apabila karyawan memiliki keinginan untuk keluar dari pekerjaannya, maka dia akan mulai malas-malasan dalam bekerja, sering absen hingga melanggar aturan-aturan yang ditetapkan perusahaan sehingga hal ini akan berdampak pada kinerja karyawan seperti barang tidak terkirim tepat waktu, barang-barang juga menumpuk digudang akibat tidak terkirimnya barang-barang ke konsumen.

Turnover karyawan umumnya merupakan isu negatif bagi perusahaan, namun dapat menjadi isu positif bila dikontrol secara tepat dan logis. Turnover sering digunakan sebagai indikator performance perusahaan dan mudah dipersepsikan secara negatif sebagai akibat bekerja sebagai batu loncatan kemudian pindah dengan diiming-imingi suatu hal yang lebih menjanjikan seolah merupakan fenomena biasa dan dianggap lumrah (Zaki dan Marzolina; 2016).

Terdapat research gap pada penelitian terdahulu yang dilakukan oleh Lestari dan Mujiati (2018) dalam judul "Pengaruh Stres Kerja, Komitmen Organisasi dan Kepuasan Kerja Karyawan terhadap Turnover Intention ” menyatakan bahwa komitmen organisasi berpengaruh negatif dan signifikan terhadap turnover intention. Sedangkan pada penelitian yang dilakukan oleh Susanti dan Palupiningdyah (2016) dalam judul "Pengaruh Kepuasan Kerja dan Komitmen Organisasi terhadap Kinerja Karyawan dengan Turnover Intention sebagai variabel intervening" menyatakan bahwa komitmen organisasi berpengaruh positif dan signifikan terhadap turnover intention. 
Penelitian yang dilakukan oleh Rolos, Sambul dan Rumawas (2018) dalam judul "Pengaruh Beban Kerja terhadap Kinerja Karyawan pada PT. Asuransi Jiwasrya Cabang Manado Kota" menyatakan bahwa beban kerja berpengaruh negatif dan signifikan terhadap kinerja karyawan. Sedangkan penelitian yang dilakukan oleh Tjiabrata, Lumanaw dan Dotulong (2017) dalam judul "Pengaruh Beban Kerja dan Lingkungan Kerja terhadap Kinerja Karyawan pada PT. Sabar Ganda Manado" menyatakan bahwa beban kerja berpengaruh positif dan signifikan terhadap kinerja karyawan.

Berdasarkan adanya research gap yang telah dibahas di atas, maka terdapat perbedaan hasil penelitian mengenai pengaruh beban kerja terhadap kinerja karyawan serta komitmen organisasi terhadap turnover intention. Sehingga masalah dalam penelitian ini adalah terdapat perbedaan hasil penelitian mengenai beban kerja, kinerja karyawan, komitmen organisasi dan turnover intention.

\section{B. TELAAH PUSTAKA}

\section{Kinerja Karyawan}

Kinerja merupakan perilaku organisasi yang secara langsung berhubungan dengan produksi barang atau penyampaian jasa. Informasi tentang kinerja organisasi merupakan suatu hal yang sangat penting digunakan untuk mengevaluasi apakah proses kinerja yang dilakukan organisasi selama ini sudah sejalan dengan tujuan yang diharapkan atau belum. Akan tetapi dalam kenyataannya, banyak organisasi yang justru kurang atau bahkan tidak jarang ada yang mempunyai informasi tentang kinerja dalam organisasinya. Kinerja sebagai hasil-hasil fungsi pekerjaan atau kegiatan seseorang atau kelompok dalam suatu organisasi yang dipengaruhi oleh berbagai faktor untuk mencapai tujuan organisasi dalam periode waktu tertentu (Mangkunegara, 2009).

Dalam organisasi, terutama yang berorientasi pada keuntungan, kinerja dianggap paling banyak berperan penting dalam menghasilkan keuntungan berkelanjutan. Dapat dikatakan bahwa kinerja karyawan ditentukan saat bekerja dengan faktor pertimbangan manajemen waktu, keterampilan kepemimpinan dan produktivitas untuk menilai setiap karyawan secara individual. Berkenaan dengan pembahasan atau pembicaraan tentang pengukuran kinerja akan dimanfaatkan sebagai dasar untuk menentukan dari indikator kinerja karyawan. Sebelum membicarakan lebih lanjut tentang pengukuran kinerja, ada beberapa hal yang perlu diperhatikan agar pengukuran kinerja itu sendiri dapat berjalan dengan lancar dan baik serta lebih efektif dan efisien. 


\section{Beban Kerja}

Beban kerja adalah besaran pekerjaan yang harus dipikul oleh suatu jabatan atau unit organisasi dan merupakan hasil kali antara volume kerja dan norma waktu (Fernando, Bode dan Lucky, 2017) Beban kerja adalah sebuah proses yang dilakukan oleh seseorang dalam menyelesaikan tugas-tugas suatu pekerjaan atau kelompok jabatan yang dilaksanakan dalam keadaan normal dalam suatu jangka waktu tertentu. Beban kerja sebagai perbedaan antara kemampuan pekerja dengan tuntutan pekerjaan, akan muncul perasaan bosan. Namun sebaliknya, jika kemampuan pekerja lebih rendah daripada tuntutan pekerjaan maka akan muncul kelelahan yang berlebih.(Hammam dan Marzolina, 2016)

Beban kerja merupakan suatu yang muncul dari interaksi antara tuntutan tugas-tugas lingkungan kerja dimana digunakan sebagai tempat kerja, keterampilan, dan persepsi dari pekerja. Beban kerja kadang-kadang didefinisikan secara operasional pada faktor-faktor tuntutan tugas atau upaya-upaya yang dilakukan untuk melakukan pekerjaan (Tarwaka 2011) . Pengukuran beban kerja diartikan sebagai suatu teknik untuk mendapatkan informasi tentang efisiensi dan efektivitas kerja suatu unit organisasi, atau pemegang jabatan yang dilakukan secara sistematis dengan menggunakan teknik analisis jabatan, teknik analisis beban kerja atau teknik manajemen lainnya.

\section{Komitmen Organisasi}

Komitmen merupakan dimensi perilaku penting yang dapat digunakan untuk menilai kecenderungan pegawai, mengidentifikasi dan keterlibatan seseorang yang relatif kuat terhadap organisasi, dan mengetahui keinginan anggota organisasi untuk tetap mempertahankan keanggotaannya dalam organisasi serta bersedia berusaha keras bagi pencapaian tujuan organisasi serta mampu menerima norma-norma yang ada dalam perusahaan tersebut (Sopiah, 2008). Komitmen organisasional adalah tingkat dimana karyawan yakin dan menerima tujuan organisasi, serta berkeinginan untuk tetap tinggal dengan organisasi tersebut. Komitmen karyawan terhadap organisasi ditunjukkan dengan keterlibatannya secara aktif dalam mencapai tujuan organisasi (Sentana dan Surya, 2017).

Komitmen karyawan merupakan tingkat keterikatan yang dimiliki karyawan terhadap perusahaannya dan dapat dijadikan jaminan untuk menjaga kelangsungan perusahaan tempat karyawan itu bekerja. Komitmen organisasional menunjukkan upaya seorang karyawan dalam melaksanakan pekerjaannya, setia pada instansinya untuk pencapaian tujuan dan pengidentifikasian karyawan dalam memenuhi tujuan organisasi (Lestari dan Mujiati, 2018). 
Komitmen kerja adalah kesanggupan anggota organisasi dalam memelihara sebuah nilai dalam upaya pencapaian tujuan organisasi bersama (Hasibuan, 2012)

Komitmen organisasional pada dasarnya berkaitan dengan kedekatan para pegawai / pegawai terhadap organisasi. Komitmen organisasi dapat merefleksikan kekuatan mengenai keterlibatan dan kesetiaan pegawai terhadap organisasi. Keterlibatan dan kesetiaan tersebut biasanya dipengaruhi oleh seberapa besar pekerjaan yang dibebankan pada pegawai / bawahan sesuai dengan harapan mereka (Firdaus, Widiana dan Fattah, 2017)

\section{Turnover Intention}

Menurut Mobley (2011) menyatakan turnover intention adalah kadar atau intensitas untuk keluar dari perusahaan. Banyak alasan yang menyebabkan timbulnya turnover intention ini dan diantaranya keinginan untuk mendapatkan pekerjaan yang lebih baik. Turnover intention ditandai dengan tingkat produktivitas kinerja karyawan pada perusahaan menurun, biasanya hal ini terjadi dengan sering datang terlambat, sering membolos atau tingkat absensi meningkat dengan berbagai alasan, kurang antusias untuk berusaha dengan baik dibanding dia masih awal bekerja.

Turnover Intention adalah kecenderungan atau keinginan berkelanjutan yang dilakukan oleh karyawan untuk meninggalkan organisasi dan digantikan oleh karyawan lain. Hal ini sering dijadikan sebagai indikator kinerja perusahaan sehingga terlihat efektivitas dan efisiensi organisasi yang negatif (Rivai, 2009).

Menurut Robbins dan Judge (2015) menyatakan bahwa turnover intention adalah kecenderungan atau tingkat dimana seseorang memiliki kemungkinan untuk meninggalkan perusahaan baik secara sukarela maupun tidak sukarela yang disebabkan kurang menariknya pekerjaan saat ini dan tersedianya alternatif pekerjaan lain.

Sekalipun sebuah organisasi berkomitmen penuh untuk membuat lingkungan kerja yang bagus dan nyaman untuk bekerja, para karyawan akan tetap untuk mengundurkan diri. Biasanya karyawan tersebut tidak melihat adanya peluang promosi, atau setidaknya tidak cukup banyak. Perputaran karyawan dalam jumlah tertentu merupakan hal yang baik bagi organisasi dan sering kali diperlukan untuk menyediakan kesempatan bagi para karyawan dalam memenuhi tujuan karirnya. Namun, ketika perputaran menjadi berlebihan, perusahaan harus melakukan sesuatu untuk menguranginya. Para karyawan yang sering kali berkualifikasi adalah karyawan yang akan melakukan pengunduran diri karena mereka lebih leluasa bergerak. Di sisi lain, para karyawan yang berkualifikasi biasa saja tampaknya akan bertahan perusahaan 
tersebut, karena jika banyak karyawan yang berkompeten meninggalkan perusahaan, maka daya saingnya akan menurun (Hafiz, 2017).

Gambar 1. Kerangka Pemikiran Teoritis

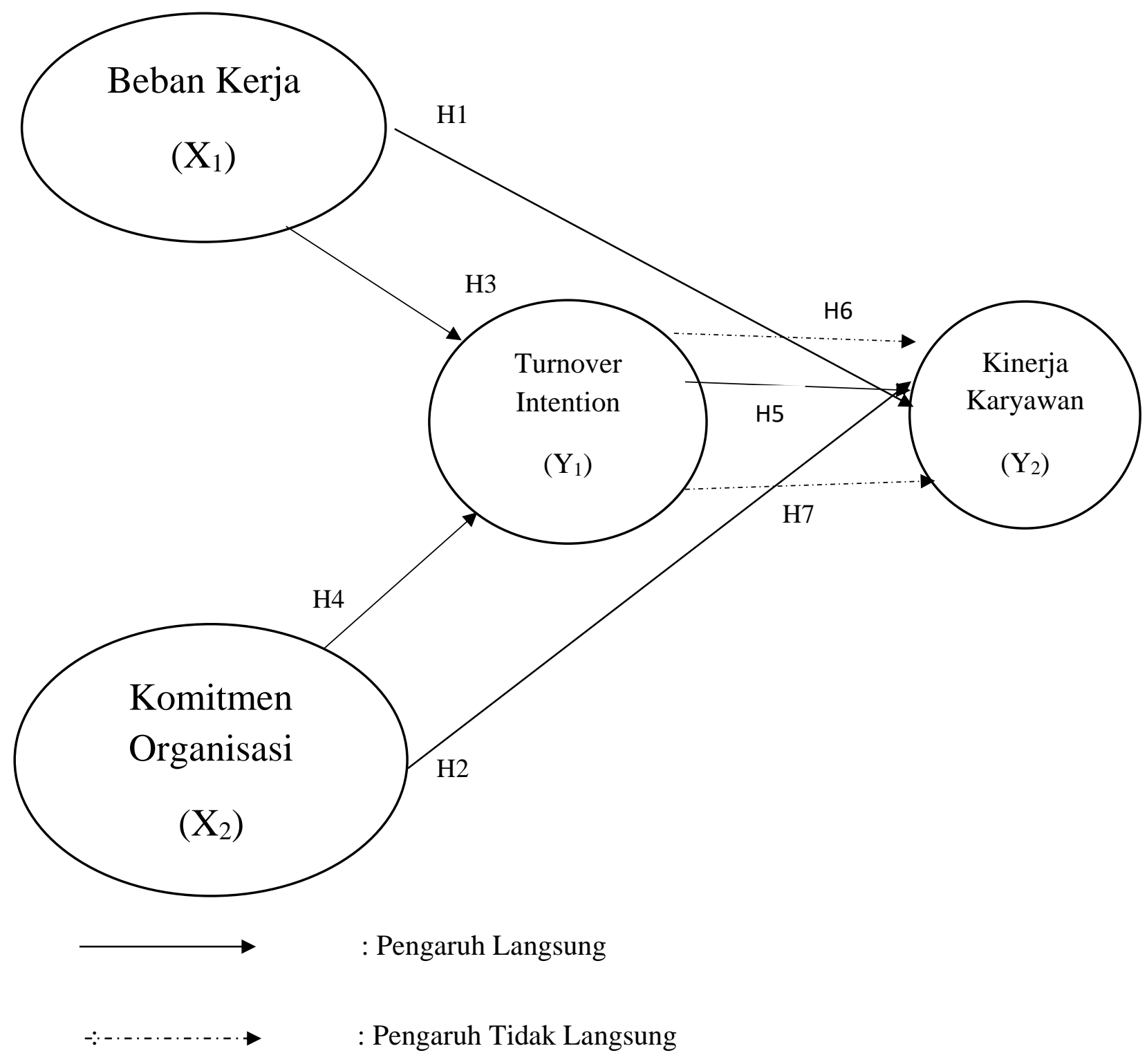

Berdasarkan telaah pustaka dan kerangka pemikiran diatas, maka hipotesis dalam penelitian ini adalah:

$\mathrm{H}_{1} \quad$ : Semakin tinggi beban kerja maka akan berpengaruh terhadap meningkatnya turnover intention

$\mathrm{H}_{2}$ : Semakin tinggi beban kerja maka akan berpengaruh terhadap menurunnya kinerja karyawan

$\mathrm{H}_{3}$ : Semakin tinggi komitmen organisasi maka akan berpengaruh terhadap menurunnya turnover intention 
$\mathrm{H}_{4}$ : Semakin tinggi komitmen organisasi maka akan berpengaruh terhadap meningkatnya kinerja karyawan

$\mathrm{H}_{5}$ : Semakin tinggi tingkat turnover intention maka akan berpengaruh terhadap menurunnya kinerja karyawan

$\mathrm{H}_{6}$ : Semakin tinggi beban kerja maka akan berpengaruh terhadap menurunnya kinerja karyawan melalui turnover intention

$\mathrm{H}_{7}$ : Semakin tinggi komitmen organisasi maka akan berpengaruh terhadap meningkatnya kinerja karyawan melalui turnover intention

\section{METODOLOGI PENELITIAN}

Penelitian ini dilakukan pada karyawan perusahaan CV Cahyono Abadi. Metode penelitian ini menggunakan metode deskriptif, yang bertujuan untuk menggambarkan sifat sesuatu yang tengah berlangsung pada saat riset dilakukan dengan memeriksa sebab-sebab dari suatu permasalahan yang muncul. Populasi dalam penelitian ini adalah seluruh karyawan yang terdiri dari bagian gudang, pengiriman barang, dan admin dengan total pegawai 180 orang. Pada penelitian ini, jumlah seluruh indikator ada 28 , maka jumlah sampel yang diambil $=5 \mathrm{x}$ $28=140$ orang. Teknik pengambilan sampel dalam penelitian ini menggunakan teknik Random Sampling. Dalam random sampling setiap bagian dalam populasi memiliki kesempatan untuk menjadi sampel.

\section{HASIL DAN PEMBAHASAN}

Responden dalam penelitian ini dibagi dalam beberapa kelompok diantaranya berdasarkan posisi pekerjaan, dan berdasarkan pendidikan. Tabel responden menurut posisi pekerjaan dan pendidikan disajikan dalam tabel 1 dan 2 berikut ini:

Tabel 1. Responden Menurut posisi pekerjaan

\begin{tabular}{|c|c|c|c|}
\hline No & Bagian & Frekuensi & Persentase \\
\hline 1 & Gudang & 78 & $55,7 \%$ \\
\hline 2 & Admin & 39 & $27,9 \%$ \\
\hline 3 & Pengiriman & 23 & $16,4 \%$ \\
\hline & Jumlah & 140 & $100 \%$ \\
\hline
\end{tabular}

Sumber : Data Primer yang Diolah, 2018

Tabel 1 menunjukkan bahwa dari 140 responden, responden terbanyak berasal dari bagian gudang sebanyak 78 orang atau $55,7 \%$, sedangkan responden paling sedikit yaitu berasal dari bagian admin sebanyak 39 orang atau 27,9\%. CV Cahyono Abadi bergerak 
dibidang distribusi barang, jadi membutuhkan lebih banyak tenaga di bagian gudang untuk kelancaran pekerjaan.

Tabel 2. Responden Menurut Pendidikan

\begin{tabular}{|c|c|c|c|}
\hline No & Pendidikan & Frekuensi & Persentase \\
\hline 1 & SMP & 43 & $30,8 \%$ \\
\hline 2 & SMA & 70 & $52,9 \%$ \\
\hline 3 & S1 & 27 & $19,3 \%$ \\
\hline & Jumlah & 140 & $100 \%$ \\
\hline
\end{tabular}

Sumber : Data Primer yang Diolah, 2018

Tabel 2 menunjukkan bahwa dari 140 responden, responden terbanyak berasal menempuh pendidikan terakhir SMA sebanyak 70 orang atau 52,9\%, sedangkan responden paling sedikit yaitu menempuh pendidikan terakhir S1 sebanyak 27 orang atau 19,3\%. CV Cahyono Abadi bergerak dibidang distribusi barang, jadi membutuhkan lebih banyak tenaga untuk pengoprasiannya tanpa mengharuskan mereka mempunyai latar belakang yang tinggi.

\section{Uji Instrumen Penelitian}

Dalam uji instrumen penelitian terdapat uji convergent validity dan uji construct reliability. Ghozali (2015) menyatakan pengukuran bisa dikatakan valid jika suatu item memiliki nilai capaian koefisien korelasi minimal 0,5. Menurut hasil uji convergent validity yang dilakukan terhadap seluruh item pertanyaan, diperoleh hasil diatas 0,5 . Hal tersebut dapat diartikan bahwa item kuesioner yang digunakan dalam penelitian ini adalah valid.

Tujuan dilakukannya uji Construct reliability adalah untuk menunjukkan keandalan dan konsistensi data. Ghozali (2015) menyatakan pengukuran bisa dikatakan reliabel jika suatu item memiliki nilai capaian Construct reliability minimal $\geq 0,7$. Hasil uji construct reliability dalam penelitian ini disajikan dalam tabel 3 berikut ini:

Tabel 3. Uji Construct reliability

\begin{tabular}{|r|l|l|l|l|}
\hline \multicolumn{1}{|c|}{ No } & \multicolumn{1}{|c|}{ Variabel } & $\begin{array}{l}\text { Hitungan } \\
\text { Construct } \\
\text { reliability }\end{array}$ & $\begin{array}{l}\text { Construct } \\
\text { reliability }\end{array}$ & Keterangan \\
\hline 1 & Beban kerja $\left(\mathrm{X}_{1}\right)$ & 0.787 & 0,70 & Reliabel \\
\hline 2 & Komitmen organisasi $\left(\mathrm{X}_{2}\right)$ & 0.943 & 0,70 & Reliabel \\
\hline 3 & Turnover intention $(\mathrm{Y} 1)$ & 0.803 & 0,70 & Reliabel \\
\hline 4 & Kinerja karyawan $(\mathrm{Y} 2)$ & 0.785 & 0,70 & Reliabel \\
\hline
\end{tabular}

Sumber: Data primer yang diolah, 2018

Dari tabel 3 dapat diketahui bahwa nilai construct reliability keempat variabel dalam penelitian ini memiliki nilai diatas 0,7 , sehingga dapat dikatakan bahwa data yang digunakan sudah konsisten dan memiliki keandalan. 


\section{Analisis Structural Equation Modelling}

Analisis structural equation modeling digunakan untuk mengetahui hubungan struktural antara variabel yang diteliti.Hubungan struktural antar variabel diuji kesesuaiannya dengan goodnessof-fit index. Hasil analisis struktural equation modeling dalam penelitian ini dapat dilihat pada Gambar 2 dibawah ini:

Gambar 2. Pengujian Full Model SEM

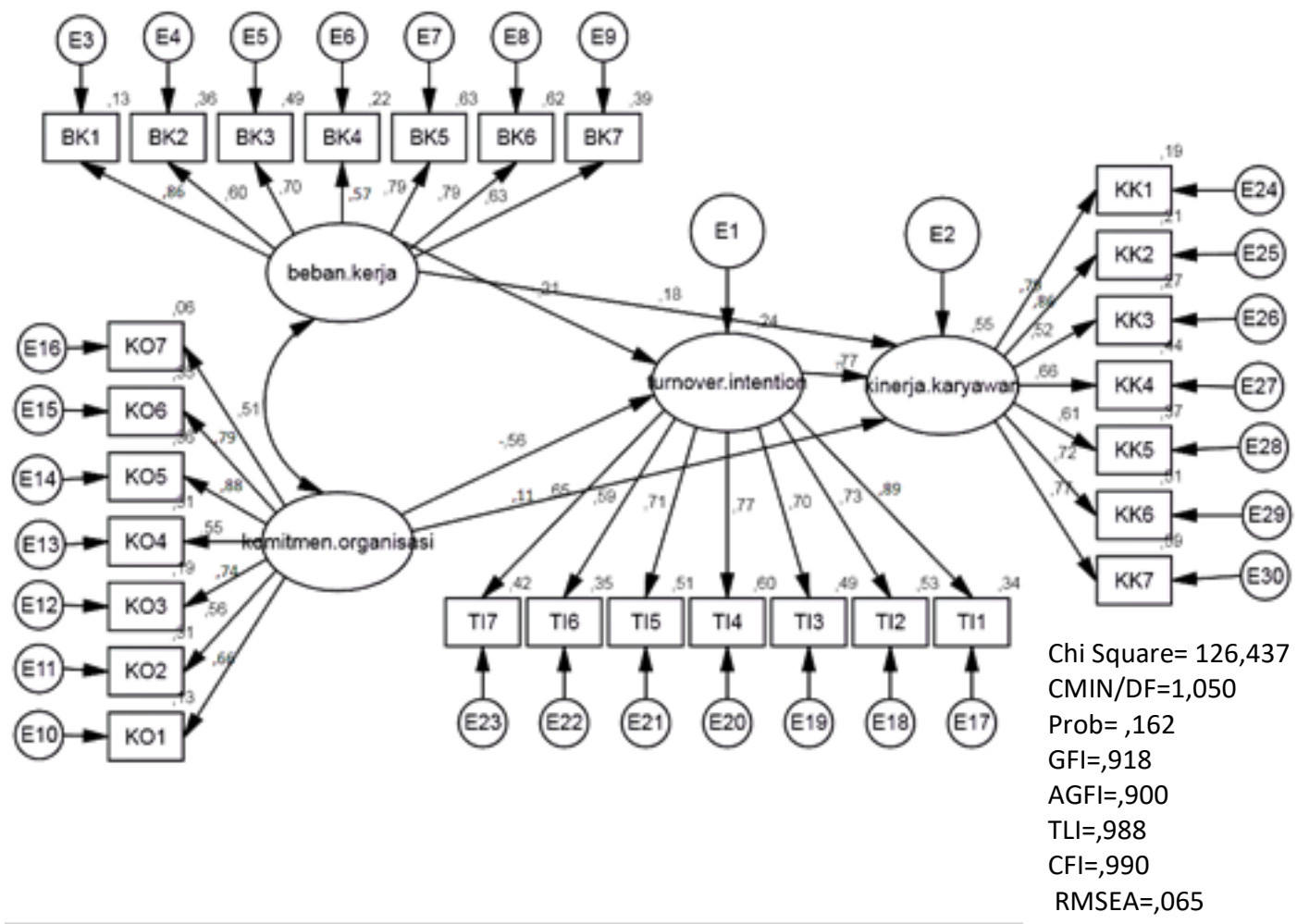

Dari gambar di atas nilai Goodness of Fit dari model full SEM dapat dilihat pada tabel 4 dibawah ini:

Tabel 4. Uji Model Goodness of Fit Variabel penelitian

\begin{tabular}{|c|c|c|c|}
\hline Goodness of index & Cut-off Value & Hasil model & Keterangan \\
\hline Chi square & Diharapkan kecil & 126,437 & Baik \\
\hline CMIN/DF & $\leq 2$ & 1,050 & Baik \\
\hline Probability & $\geq 0,05$ & 0,162 & Baik \\
\hline GFI & $\geq 0,90$ & 0,918 & Baik \\
\hline AGFI & $\geq 0,90$ & 0,900 & Baik \\
\hline TLI & $\geq 0,90$ & 0,988 & Baik \\
\hline CFI & $\geq 0,90$ & 0,990 & Baik \\
\hline RMSEA & $\leq 0,08$ & 0,065 & Baik \\
\hline
\end{tabular}

Sumber : Hasil Perhitungan AMOS, 2018

Berdasarkan tabel 4 di atas diperoleh nilai chi square 126,437 dengan nilai CMIN/DF sebesar 1.050, probabilitas 0,162, nilai GFI sebesar 0,918, nilai AGFI sebesar 0,900, nilai TLI sebesar 0.988, nilai CFI sebesar 0.990 dan nilai RMSEA sebesar 0,065 menunjukkan bahwa 
uji kesesuaian model ini menghasilkan sebuah penerimaan yang baik. Oleh karena itu, dapat disimpulkan bahwa indikator-indikator itu merupakan dimensi acuan yang sama bagi konstruk dapat diterima. Dengan kata lain, 28 indikator tersebut secara nyata membentuk variabel full model.

\section{Uji Hipotesis}

Uji hipotesis dilakukan untuk mengetahui berpengaruh atau tidaka nya variabel independen terhadap variabel dependen. Hipotesis dinyatakan diterima jika nilai prob $(\mathrm{P})<$ 0,05. Hasil uji hipotesis dapat dilihat pada tabel 5.

Tabel 5. Hasil Uji Hipotesis

Scalar Estimates (Group number 1 - Default model)

Maximum Likelihood Estimates

Regression Weights: (Group number 1 - Default model)

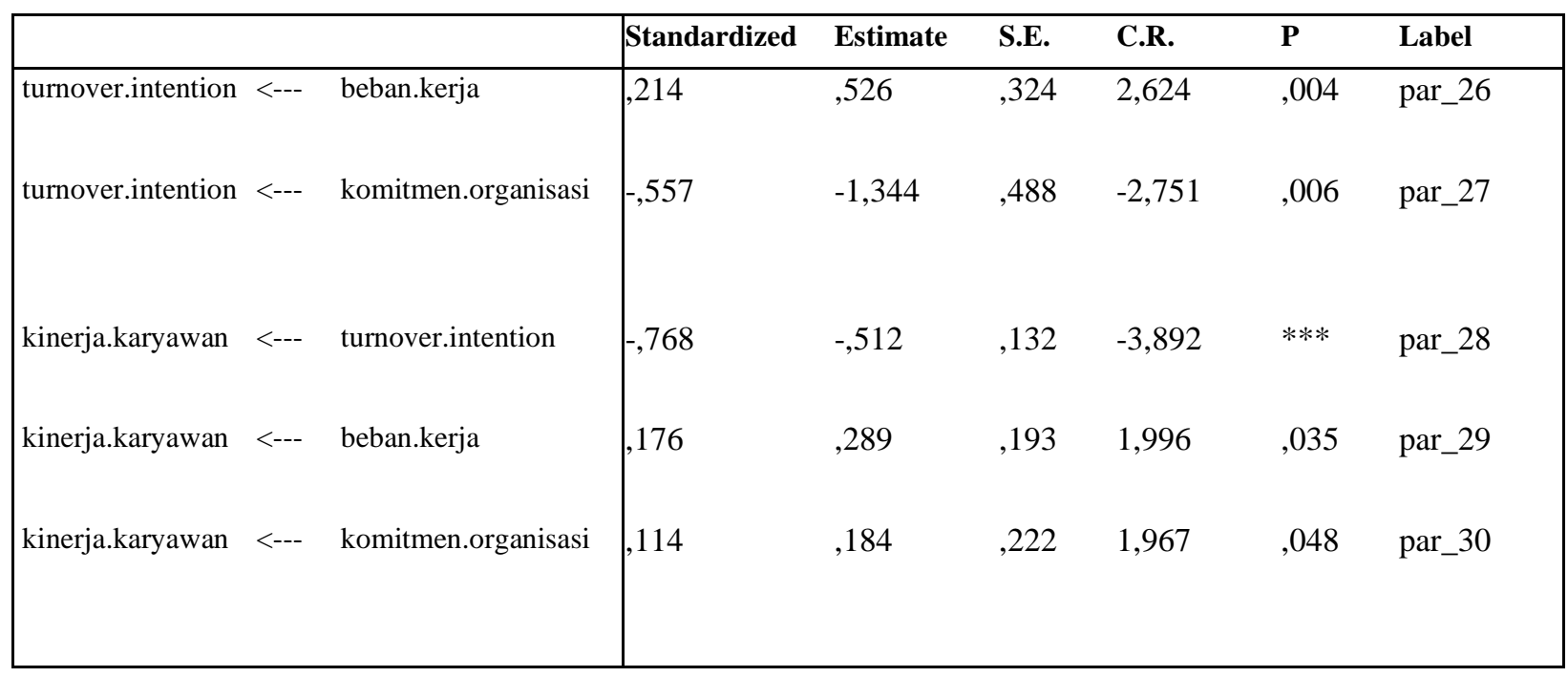

Sumber : Hasil Perhitungan AMOS, 2018

\section{Pengaruh Beban kerja terhadap turnover intention}

Berdasarkan data dari hasil pengolahan data diketahui bahwa nilai CR sebesar 2,624 dan nilai $\mathrm{P}$ (probability) 0,004<0,05. Nilai ini menunjukkan hasil yang memenuhi syarat yaitu kurang dari 0,05 untuk P sehingga dapat disimpulkan $\mathrm{H} 1$ pada penelitian ini diterima. Nilai standarized estimate pengaruh beban kerja terhadap turnover intention sebesar 0,214. Hal ini mengindikasikan bahwa beban kerja mampu mempengaruhi turnover intention sebesar 0,214\%. Hal ini bisa dinyatakan bahwa ketika beban kerja yang diberikan oleh pihak perusahaan dirasa terlalu memberatkan dan melebihi batas yang mereka mampu maka hal tersebut berdampak pada tingkat turnover intention karyawan. Beban kerja seharusnya merupakan hal yang wajar demi pertumbuhan perusahaan dan karyawan sendiri, tetapi ketika 
hal tersebut dimaknai sebagai hal yang negatif maka berdampak pada ketidak nyamanan karyawan yang kurang mempunyai etos kerja yang tinggi.

Hasil penelitian ini mendukung teori yang diungkapkan oleh Irvianti dan Verina (2015) dimana beban kerja memberikan pengaruh yang cukup besar terhadap turnover intention. Salah satu upaya yang dapat dilakukan oleh perusahan untuk mengurangi beban kerja terhadap karyawan adalah dengan melakukan perekrutan karyawan baru yang cukup berpengalaman karena apabila perusahaan kekurangan karyawan, maka karyawan akan merasakan beban kerja yang berlebih karena tugas-tugas yang diberikan terlalu banyak sehingga menyebabkan karyawan menggunakan jam istirahat untuk menyelesaikan tugas. Hal ini sesuai dengan penelitian Penelitian Renno Eka Verrina (2015), yang menguji pengaruh beban kerja terhadap turnover intention. Pernyataan senada juga diungkapkan oleh Ni Wayan Pujiati (2018) yang menyatakan bahwa beban kerja berpengaruh terhadap turnover intention.

\section{Pengaruh komitmen organisasi terhadap turnover intention}

Berdasarkan data dari hasil pengolahan data diketahui bahwa nilai CR sebesar -2,751 dan nilai $\mathrm{P}$ (probability) $0,006<0,05$. Nilai ini menunjukkan hasil yang memenuhi syarat yaitu kurang dari 0,05 untuk $\mathrm{P}$ sehingga dapat disimpulkan $\mathrm{H} 2$ pada penelitian ini diterima. Nilai standarized estimate pengaruh komitmen organisasi terhadap turnover intention sebesar 0,557. Hal ini mengindikasikan bahwa komitmen organisasi mampu mempengaruhi turnover intention sebesar $0,557 \%$. Berdasarkan hasil tersebut dapat dinyatakan bahwa ketika komitmen organisasi yang miliki karyawan meningkat hal tersebut akan menurunkan tingkat turnover intention karyawan. Komitmen organisasi menumbuhkan rasa loyalitas karyawan kepada perusahaan dimana karyawan merasa ikut berperan dalam mengembangkan perusahaan, komitmen organisasi juga meningkatkan motivasi karyawan untuk terus bekerja dan memberikan yang terbaik untuk kemajuan perusahaan.

Penerimaan hipotesis ini sejalan dengan pernyataan yang diungkapkan oleh Ni Wayan (2018) dimana komitmen karyawan merupakan tingkat keterikatan yang dimiliki karyawan terhadap perusahaannya dan dapat dijadikan jaminan untuk menjaga kelangsungan perusahaan tempat karyawan itu bekerja. Komitmen organisasional menunjukkan upaya seorang karyawan dalam melaksanakan pekerjaannya, setia pada instansinya untuk pencapaian tujuan dan pengidentifikasian karyawan dalam memenuhi tujuan organisasi (Lestari dan Mujiati, 2018). Hal ini sejalan dengan penelitian Ahmed dan Nawaz (2015). yang menguji hubungan antara komitmen organisasi dengan turnover intention yang menyimpulkan komitmen organisasi berpengaruh negatif dan signifikan terhadap turnover intention. 


\section{Pengaruh Beban kerja terhadap kinerja karyawan}

Berdasarkan data dari hasil pengolahan data diketahui bahwa nilai CR sebesar 1,996 dan nilai $\mathrm{P}$ (probability) $0,035<0,05$. Nilai ini menunjukkan hasil yang memenuhi syarat yaitu kurang dari 0,05 untuk P sehingga dapat disimpulkan $\mathrm{H} 3$ pada penelitian ini diterima. Nilai standarized estimate pengaruh beban kerja terhadap kinerja karyawan sebesar 0,176. Hal ini mengindikasikan bahwa beban kerja mampu mempengaruhi kinerja karyawan sebesar $0,176 \%$. Hal ini bisa dinyatakan bahwa ketika beban kerja meningkat maka hal tersebut dapat meningkatkan kinerja karyawan.

Pernyataan ini sesuai dengan pendapat yang disampaikan oleh Fernando, Bode dan Lucky, (2017) yang menyatakan bahwa beban kerja merupakan faktor ekstrinsik individu yang menjadi salah satu sumber munculnya tekanan, karena beban kerja yang dihadapinya terlalu banyak. Kondisi ini menuntut pegawai untuk memberikan energi yang lebih besar lagi daripada biasanya di dalam menyelesikan pekerjannya, tetapi semua ini tergantung pada masing-masing individualnya, maksudnya tugas-tugas tersebut akan selesai dengan baik atau tidak tergantung bagaimana seseorang menghayati beban kerja yang di rasakanya. Hasil ini sejalan dengan penelitian Sujarwanto (2016) dimana beban kerja berpengaruh positif signifikan terhadap kinerja karyawan.

\section{Pengaruh komitmen organisasi terhadap kinerja karyawan}

Berdasarkan data dari hasil pengolahan data diketahui bahwa nilai CR sebesar 1,967 dan nilai $\mathrm{P}$ (probability) $0,048<0,05$. Nilai ini menunjukkan hasil yang memenuhi syarat yaitu kurang dari 0,05 untuk $\mathrm{P}$ sehingga dapat disimpulkan $\mathrm{H} 4$ pada penelitian ini diterima. Nilai standarized estimate pengaruh komitmen organisasi terhadap kinerja karyawan sebesar 0,114. Hal ini mengindikasikan bahwa komitmen organisasi mampu mempengaruhi kinerja karyawan sebesar $0,114 \%$. . Berdasarkan hasil uji tersebut dapat dinyatakan bahwa tumbuhnya komitmen organisasi yang dimiliki karyawan nantinya akan meningkatkan kinerja karyawan tersebut.

Hasil ini konsisten dengan penelitian Susanti dan Palupiningdyah (2016) yang menyatakan bahwa komitmen organisasi berpengaruh terhadap kinerja karyawan. Hal ini sesuai dengan penelitian Khan, Ziauddin, Jam (2014) yang menguji pengaruh antara komitmen organisasi terhadap kinerja karyawan, yang menyatakan bahwa komitmen organisasi berpengaruh secara positif dan signifikan terhadap kinerja karyawan.

\section{Pengaruh Turnover intention terhadap kinerja karyawan.}

Berdasarkan data dari hasil pengolahan data diketahui bahwa nilai CR sebesar -3,892 dan nilai $\mathrm{P}$ (probability) $0,000<0,05$. Nilai ini menunjukkan hasil yang memenuhi syarat yaitu 
kurang dari 0,05 untuk P sehingga dapat disimpulkan H5 pada penelitian ini dapat diterima. Nilai standarized estimate pengaruh komitmen organisasi terhadap kinerja karyawan sebesar 0,762. Hal ini mengindikasikan bahwa komitmen organisasi mampu mempengaruhi kinerja karyawan sebesar $0,762 \%$.

Adanya keinginan keluar dari pekerjaan atau organisasi menyebabkan karyawan melakukan pekerjaan tidak sesuai dengan prosedur yang ada di organisasi, sehingga secara otomatis menyebabkan performa karyawan menurun. Semakin tinggi nilai turnover intention karyawan maka menyebabkan kinerja karyawan semakin menurun. Hal ini sesuai dengan penelitian Ahmed dan Nawaz (2015) yang menguji hubungan antara turnover intention dengan kinerja karyawan.

Hasil uji menyatakan bahwa variabel beban kerja mempunyai nilai direct effect sebesar 0,176 dan indirect effect sebesar - 0.165 dengan total effect sebesar 0,011. Nilai direct effect lebih besar dibandingkan dengan nilai indirect effect (0,176>-0.165). Keputusan uji mediasi yang bisa diambil adalah turnover intention tidak bisa menjadi variabel mediasi hubungan antara beban kerja terhadap kinerja karyawan. Hal ini bisa dinyatakan bahwa beban kerja dalam mempengaruhi prestasi belajar secara langsung lebih besar pengaruhnya dari pada harus melewati variabel turnover intention.

Hasil penelitian ini memberikan gambaran bahwa beban kerja lebih menyasar pada kinerja karyawan. Turnover intention tidak mampu memediasi hubungan pengaruh beban kerja terhadap kinerja karyawan. Karyawan merasa beban kerja yang mereka terima dipandang sebagai penyemangat atas kinerja yang mereka capai. Hasil penelitian ini senada dengan hasil penelitian yang dilakukan oleh oleh Tjiabrata, dkk (2017) yang menyatakan bahwa turnover intention bukan merupakan variabel intervening daintara pengaruh beban kerja terhadap kinerja karyawan karyawan.

Hasil uji menyatakan bahwa variabel komitmen organisasi mempunyai nilai direct effect sebesar 0.114 dan indirect effect sebesar 0,428 dengan total effect sebesar 0,542. Nilai direct effect lebih kecil dibandingkan dengan nilai indirect effect. Keputusan uji mediasi yang bisa diambil adalah turnover intention bisa menjadi variabel mediasi hubungan antara komitmen organisasi terhadap kinerja karyawan. Komitmen organisasi yang melewati variabel turnover intention mempunyai pengaruh yang lebih besar dibandingkan dengan komitmen organisasi yang secara langsung mempengaruhi kinerja karyawan. Hasil penelitian ini mendukung penelitian yang dialakukan oleh Ahmed dan Nawaz (2015) yang menyatakan bahwa turnover 
intention merupakan variabel intervening antara pengaruh komitmen organisasi terhadap kinerja karyawan karyawan.

\section{E. KESIMPULAN}

Berdasarkan penelitian yang dilakukan maka terdapat beberapa hal yang dapat disimpulkan. Beban kerja berpengaruh positif signifikan terhadap turnover intention dan kinerja karyawan. Hal ini berarti bahwa ketika beban kerja yang dirasakan meningkat maka turnover intention karyawan akan ikut bertambah. Selain itu, ketika beban kerja meningkat maka kinerja karyawan karyawan akan ikut bertambah.

Hasil penelitian ini juga menunjukkan bahwa komitmen organisasi berpengaruh negatif signifikan terhadap turnover intention. Ketika komitmen organisasi yang dimiliki oleh karyawan menurun maka hal tersebut dapat meningkatkan turnover intention karyawan. Di sisi lain komitmen organisasi berpengaruh positif signifikan terhadap kinerja karyawan. Dengan demikian, ketika komitmen organisasi yang yang dimiliki oleh karyawan menurun maka hal tersebut dapat meningkatkan kinerja karyawan karyawan. Di samping itu, penelitian ini membuktikan bahwa turnover intention berpengaruh negatif dan signifikan terhadap kinerja karyawan. Hal ini berarti turnover intention yang meningkat akan dapat menurunkan kinerja karyawan.

Hasil lain yang ditunjukkan dalam penelitian ini adalah turnover intention tidak memediasi hubungan antara beban kerja terhadap kinerja karyawan. Namun, turnover intention bisa menjadi variabel mediasi hubungan antara komitmen organisasi terhadap kinerja karyawan.

\section{DAFTAR PUSTAKA}

Ahmed, M. dan Nawaz, N. 2015. Impact of Organizational Commitment on Employee Turnover : A Case Study of Pakistan International Airlines. Industrial Engineering Letters, Vol. 5, No. 8, Page. 57-69

Firdaus, S., Widiana, M. E dan Fattah, A. 2017. Pengaruh Lingkungan Kerja, Stres Kerja dan Komitmen Organisasi terhadap Turnover Intention pada PT. Supranusa Indogita Tbk. Sidoarjo, Jurnal Manajemen Branchmark, Vol 3, Issue 3, Hal. 733-745

Ghozali, Imam. 2015. Aplikasi Analisis Multivariate dengan Program IBM SPSS. 23. Semarang : Badan Penerbit Universitas Diponegoro.

Hafiz, A.Z. 2017. Relationship between Organizational Commitment and Employee's Performance Evidence from Banking Sector of Lahore. Arabian J Bus Manag Review, an open access journal, Vol. 7, Issue. 2, Page: 1-7 
Hasibuan, M. 2012. Manajemen Sumber Daya Manusia. Jakarta: PT. Bumi Aksara.

Irvianti, L.S.D dan Verina, R.E. 2015. Analisis Pengaruh Lingkungan Kerja, Beban Kerja, Stres Kerja terhadap Turnover Intention pada PT. XL Axiata Tbk. Jakarta. Binus Business Review, Vol. 6 No. 1 Hal: 117-126.

Lestari, N.N.Y.S dan Mujiati, N.W. 2018. Pengaruh Stres Kerja, Komitmen Organisasi dan Kepuasan Kerja terhadap Turnover Intention pada PT. Bank Rakyat Indonesia (Persero) Tbk. Cabang Denpasar. E-Jurnal Manajemen Unud, Vol. 7, No. 6 Hal: 3412-3441.

Khan, M.R, Ziauddin, Ahmed, A.F. 2014. The Impact of Organizational Commitment on Employee Job Performance. European Journal of Social Scienes, Vol. 15, No. 3, Page. 292-298

Mangkunegara, A.P. 2009. Manajemen Sumber Daya Manusia. Bandung: PT. Remaja Rosdakarya.

Mobley, W. H. 2011. Pergantian Karyawan: Sebab, Akibat dan Pengendaliannya. Alih Bahasa : Nurul Imam, Jakarta: PT. Pustaka Binaman Pressindo

Rivai, V. 2009. Manajemen Sumber Daya Manusia Untuk Perusahaan Dari Teori ke Praktik. Jakarta: Raja Grafindo Persada.

Robbins, S. P. dan Timothy A. Judge. 2008. Perilaku Organisasional, Buku 1 dan 2. Jakarta: Salemba Empat. 2015. Perilaku Organisasi, Edisi 16. Jakarta: Salemba Empat

Rolos, Jeky K. R., Sambul, Sofia A. P., dan Rumawas, Wehelmina. 2018. Pengaruh Beban Kerja terhadap Kinerja Karyawan pada PT. Asuransi Jiwasraya Kota Manado. Jurnal Administrasi Bisnis, Vol. 6 No. 4, Hal. 19-27

Sentana, I.K.A.D dan Surya, I.B.K. 2017. Pengaruh Kepuasan Kerja dan Komitmen Karyawan terhadap Turnover Intention pada Manis Gallery. E-Jurnal Manajemen Unud, Vol. 6, No. 10 : 5232-5261.

Sopiah. 2008. Perilaku Organisasi. Yogyakarta: Andi Offset.

Susanti dan Palupiningdyah. 2016. Pengaruh Kepuasan Kerja dan Komitmen Organisasi terhadap Kinerja Karyawan dengan Turnover Intention sebagai Variabel Intervening pada PT. Milan Indonesia. Management Analysis Journal 5 (1), Hal. 77-86

Syed, S. et al. 2014. Workload and Performance Employees. Interdisciplinary Journal Of Contemporary Research In Business, Vol. 3 No. 5, Page. 256-268

Tarwaka. 2011. Ergonomi Industri, Dasar-Dasar Pengetahuan Ergonomi dan Aplikasi Di Tempat Kerja. Surakarta: Harapan Press.

Tjiabrata, Fernando Reinhard, Lumanaw, Bode dan Dotulong, Lucky O.H.. 2017. Pengaruh Beban Kerja dan Lingkungan Kerja terhadap Kinerja Karyawan PT. Sabar Ganda Manado, Jurnal EMBA, Vol. 5, No. 2, Hal. 1570-1580. 
Zaki, Hamam dan Marzolina. 2016. Pengaruh Beban Kerja dan Kompensasi terhadap Kepuasan Kerja melalui Turnover Intention sebagai variabel intervening. Jurnal Tepak Manajemen Bisnis, Vol. VIII No. 3, Hal. 1-23 